\title{
Analysis of Fraxinus pollen seasons and forecast models based on meteorological factors
}

\author{
Agnieszka Kubik-Komar ${ }^{1, A, C-F}$, Krystyna Piotrowska-Weryszko ${ }^{2, A-B, D-F}$, \\ Elżbieta Weryszko-Chmielewska ${ }^{2, B, D-F}$, Bogusław Michał Kaszewski ${ }^{3, B, E-F}$ \\ ${ }^{1}$ Department of Applied Mathematics and Computer Science, University of Life Sciences, Lublin, Poland \\ ${ }^{2}$ Department of Botany, University of Life Sciences, Lublin, Poland \\ ${ }^{3}$ Department of Meteorology and Climatology, Maria Skłodowska-Curie University, Lublin, Poland \\ A - Research concept and design, B - Collection and/or assembly of data, C - Data analysis and interpretation, \\ $D$ - Writing the article, E - Critical revision of the article, F - Final approval of article
}

Kubik-Komar A, Piotrowska-Weryszko K, Weryszko-Chmielewska E, Kaszewski BM. Analysis of Fraxinus pollen seasons and forecast models based on meteorological factors. Ann Agric Environ Med. 2018; 25(2): 285-291. doi: 10.26444/aaem/80909

\begin{abstract}
Introduction and objective. The timings of Fraxinus and Betula flowering and pollen release overlap, which may cause increased allergic reactions in sensitive people. The aim of the present study was to characterize Fraxinus pollen seasons in Lublin (central-eastern Poland) and to identify meteorological factors that most determine the occurrence of airborne pollen of this taxon, as well as obtain forecast models for the basic characteristics of the pollen season.

Materials and method. The study was conducted in Lublin during the period 2001-2016, employing the volumetric method. The seasons were compared by PCA (Principal Component Analysis). To determine relationships between meteorological conditions and the pattern of pollen seasons, regression analysis was used. Data for the period 2001-2015 were used to create forecast models by applying regression analysis, while the 2016 data served to verify these models.

Results. Season end date and seasonal peak date were characterized by the lowest variation. The biggest differences were found for peak value and total annual pollen sum. The average dates of occurrence of ash pollen grains in the air of Lublin were between 13 April 13 - 3 May 3, whereas, on average, the pollen peak date occurred on 23 April. The factor loading values for the PC1 variable indicate that it is most strongly correlated with peak value and total pollen sum, while the PC2 variable correlated with the pollen season start date and season duration (a negative correlation). Regression models were developed for the following pollen season characteristics: season start, end and duration, seasonal peak date, and total annual pollen sum.

Conclusions. The fit of the forecast models was at the level of $62-94 \%$. Analysis of the data showed that weather conditions mainly in February were important factors controlling the Fraxinus pollen season.
\end{abstract}

\section{Key words}

allergy, regression analysis, aerobiology, airborne pollen, Fraxinus

\section{INTRODUCTION}

Trees of the genus Fraxinus (f. Oleaceae) comprising 65 species grow in temperate areas of the Northern Hemisphere [1]. In Poland, the only native species is Fraxinus excelsior L. This species occurs in central and southern Europe, in the Caucasus and Asia Minor [1,2,3].

F. excelsior is frequently found in moist forests and river valleys. It is also planted in parks, and along avenues and roads. For urban plantings, other species of this genus are also used: F. americana and F. pensylvanica originating from North America, as well as F. ornus and F. angustifolia from southern Europe [1]. In Poland, the flowering of F. excelsior occurs in April and May. The average number of pollen grains produced by one flower of this species is 25,050 , while for one inflorescence it is $1,605,700$ [4].

In the Oleaceae family, Fraxinus is one of the sources of pollen allergens. Olea europaea belongs to species of major importance in the etiology of allergic diseases in the Mediterranean region [5]. Because one of the main

Address for correspondence: Krystyna Piotrowska-Weryszko Department of Botany University of Life Sciences, Akademicka 15, 20-095 Lublin, Poland e-mai: krystyna.piotrowska@up.lublin.pl

Received: 08.05.2017; accepted: 30.11.2017; first published: 18.01.2018
Fraxinus pollen allergens, Fra e 1 with a molecular mass of $7 \mathrm{kDa}$, exhibits homology with an Olea pollen allergen, Ole e $1(16 \mathrm{kDa})$, in patients with hypersensitivity to ash pollen allergens there is a risk of cross-reactions $[6,7,8]$. The possibility of occurrence of cross-reactions in allergy sufferers sensitive to Fraxinus pollen also applies to other species belonging to Oleaceae and planted as ornamental shrubs: Ligustrum, Forsythia, Syringa, Jasminum [7, 8, 9].

In central Europe the main pollen season of Fraxinus largely overlaps with the Betula pollen shed period. Betula pollen causes allergy in a substantial part of pollen-sensitive people in Poland (14.9\%) [10]. Research also confirms that there is a risk of cross-reactions between Betula and Fraxinus pollen allergens [7]. The above-mentioned author also reports that patients allergic to Alnus and Corylus pollen are also frequently sensitized to Fraxinus pollen. The possible incidence of allergies to Fraxinus pollen is aggravated by the presence of allergens in orbicules on the exine surface and on the inner surface of anthers of the above-mentioned taxon during pollen release [11].

Research on Fraxinus in Poland can be found in [12] and [13] where the concentration comparison of this taxon in different Polish regions is presented, as well as in [14] where the hourly distribution of pollen count and the correlation between pollen concentration of Fraxinus and some 
environmental factors were studied. However, the risk of allergy to Fraxinus is still scarcely reported. Some authors have determined the threshold values for Fraxinus pollen concentrations that cause allergy symptoms in the average patient. Horak et al. [15] report that for the Czech Republic this concentration is $167 \mathrm{P} / \mathrm{m}^{3}$. In Switzerland, on the other hand, the threshold value was determined to be $100 \mathrm{P} / \mathrm{m}^{3}$, while in Austria $90 \mathrm{P} / \mathrm{m}^{3}$, but these values were determined without investigating allergic symptoms in patients. The reported values are within the limits of moderate (16-90) and high (91-1500) tree pollen concentrations, as determined by Frenz [16]. In this study, it was assumed that high $\left(>90 \mathrm{P} / \mathrm{m}^{3}\right)$ daily pollen concentrations [16] may be a risk of allergy in susceptible individuals.

Multivariate methods are widely used in aerobiological studies, the most popular of which are PCA, cluster analysis and regression. The latter is commonly used in forecast modeling [17, 18, 19]. In this study, stepwise multiple regression was applied [5]. The application of PCA as well as cluster analysis in aerobiological studies can be found in articles [20,21].

\section{OBJECTIVES}

Despite the articles mentioned above, information on the Fraxinus pollen season in Poland is still limited and insufficient. Therefore, the aim of this study was to compare the pattern of Fraxinus pollen seasons in Lublin during the period 2001-2016, to determine the effects of meteorological factors on their dynamics, and to develop regression models to forecast the major parameters of the Fraxinus pollen season. In assessment of the risk of pollen allergy, it is important to determine the number of days of high pollen concentration during a season, which is more than $90 \mathrm{P} / \mathrm{m}^{3}$ for trees. The number of days on which there was such a risk was determined for individual years.

\section{MATERIAL AND METHODS}

This study on monitoring airborne Fraxinus pollen grains was conducted in Lublin (central-eastern Poland) during the period 2001-2016. Average daily pollen concentrations were measured with a Hirst-type pollen trap (Lanzoni VPPS 2000). The pollen trap was located on the flat roof of a building of the University of Life Sciences at an altitude of $197 \mathrm{~m}$, and at a height of $18 \mathrm{~m}$ above ground level. Standard methods applied in aerobiological research were employed for analysis [22]. Results were expressed as the number of pollen grains per $1 \mathrm{~m}^{3}$ of air per 24 hours $\left(\mathrm{P} / \mathrm{m}^{3}\right)$. The following parameters of the pollen season were analyzed: start, end, duration, maximum daily pollen concentration (peak value), maximum daily concentration date (peak date), and total annual pollen sum of average daily pollen concentration. The 95\% method was used to calculate the start and end of the pollen seasons [23].

Principal component analysis (PCA) was used to compare the pollen seasons, at the same time taking into account the individual season characteristics. 15 pollen seasons and 6 season characteristics were treated as a data matrix. The aim of this analysis was to find two new parameters that would allow the pollen season characteristics in individual years to be presented graphically on one plot. Factor loading values were determined after a normalized varimax rotation so as to ensure that the new variables, PC1 and PC2, would provide the highest possible percentage of the explained variance. The factor scores shown in the plot, whose axes were the determined variables, allowed quick identification of the years with similar values of the season characteristics.

Ash pollen seasons were also analyzed in relation to weather conditions. The meteorological data came from the Meteorological Observatory of the Meteorology and Climatology Department, the Maria Curie-Skłodowska University in Lublin, which is located at a distance of about $1.5 \mathrm{~km}$ from the pollen sampling site. The following meteorological data were used for the analysis: mean, minimum and maximum air temperature, relative air humidity, rainfall, cloud cover, and wind speed. To determine relationships between meteorological conditions and season characteristics, Spearman's correlation coefficient was applied, while at a further stage, regression analysis was employed. The 2001-2015 data were used as a learning sample to find regression models for the individual season characteristics. 10-day data for the meteorological factors were used as independent variables; the data matrix therefore consisted of 15 seasons and 72 variables (4 months $\mathrm{x} 3$ decades x 6 meteorological factors). The wind speed was not taken into consideration due to some missing values. Similar to the study by Stach et al. [17], to prevent multicollinearity, it was decided not to enter highly correlated independent variables into the multiple regression models. For example, from maximum, mean and minimum temperatures of the same 10-day period, only one of these parameters was included in the model (if any). In seeking optimal functions that would reflect betweenyear variations in the characteristics of the seasons, a multiple and polynomial regression was conducted, entering stepwise the individual variables into the model and thus building step by step the best regression model $[24,25]$. The bestfitting regression model was chosen based on the value of the adjusted coefficient of determination $\left(A d j \mathrm{R}^{2}\right)$. The predictive power was verified by calculating the model's values for the 2016 data and comparing them with the actual values.

\section{RESULTS}

On average, the Fraxinus pollen season started on 13 April (Tab. 1). The difference in the extreme season start dates was 21 days over the study period. The earliest season onset was recorded in 2002 (2 April) and the latest in 2006 and 2013 (23 April). The coefficient of variation of the characteristic in question was $6.4 \%$. It is worth stressing that in the last 3 years (2014-2016) the season began earlier than the 16-year average would indicate. Season end date was characterized by much lower variations ( $\mathrm{V}=2.7 \%)$. On average, the season end was recorded on 3 May, with the earliest date on 26 April (2014) and the latest on 7 May (2006) (Fig. 1). The ash pollen season lasted, on average, 3 weeks, and the difference between the shortest and longest season was 16 days. The longest pollen seasons occurred in the years 2001, 2002 and 2005 (on average, 29 days), but in most years during the period 2003 2013 their average duration was much shorter (18 days). In the years $2014-2016$, however, there was an extension in season duration (average season duration - 24 days). Seasonal peaks and total annual pollen sums were characterized by very high 
Table 1. Statistics of the parameters of the Fraxinus pollen season in Lublin in 2001-2016

\begin{tabular}{|c|c|c|c|c|c|c|c|}
\hline \multirow[t]{2}{*}{ Statistics } & \multicolumn{2}{|c|}{ Pollen season } & \multirow{2}{*}{$\begin{array}{c}\text { Duration } \\
\text { (days) }\end{array}$} & \multicolumn{2}{|c|}{ Peak } & \multirow{2}{*}{$\begin{array}{c}\begin{array}{c}\text { Annual } \\
\text { total }\end{array} \\
\text { (pollen } \\
\text { sum) }\end{array}$} & \multirow{2}{*}{$\begin{array}{c}\text { Day number } \\
\text { with count } \\
\text { above } \\
\text { threshold }\end{array}$} \\
\hline & Start & End & & $\mathrm{P} / \mathrm{m}^{3}$ & Date & & \\
\hline Mean & $13 / 4$ & $3 / 5$ & 21 & 286 & $23 / 4$ & 1791 & 6 \\
\hline Min & $\begin{array}{c}2 / 4 \\
(2002)\end{array}$ & $\begin{array}{c}26 / 4 \\
(2014)\end{array}$ & $\begin{array}{c}14 \\
(2013)\end{array}$ & $\begin{array}{c}82 \\
(2016)\end{array}$ & $\begin{array}{c}13 / 4 \\
(2010)\end{array}$ & $\begin{array}{c}759 \\
(2009)\end{array}$ & $\begin{array}{c}0 \\
(2016)\end{array}$ \\
\hline Max & $\begin{array}{l}23 / 4 \\
(2006 \\
2013)\end{array}$ & $\begin{array}{c}7 / 5 \\
(2006)\end{array}$ & $\begin{array}{c}30 \\
(2001)\end{array}$ & $\begin{array}{c}545 \\
(2006)\end{array}$ & $\begin{array}{c}2 / 5 \\
(2001)\end{array}$ & $\begin{array}{c}3232 \\
(2006)\end{array}$ & $\begin{array}{c}12 \\
(2011 \\
2015)\end{array}$ \\
\hline SD & 6.6 & 3.4 & 5.3 & 130.2 & 5.7 & 757.4 & 3.5 \\
\hline V (\%) & 6.4 & 2.7 & 25.8 & 45.6 & 5.1 & 42.3 & 56.8 \\
\hline
\end{tabular}

SD - standard deviation

$\mathrm{V}$ - coefficient of variation

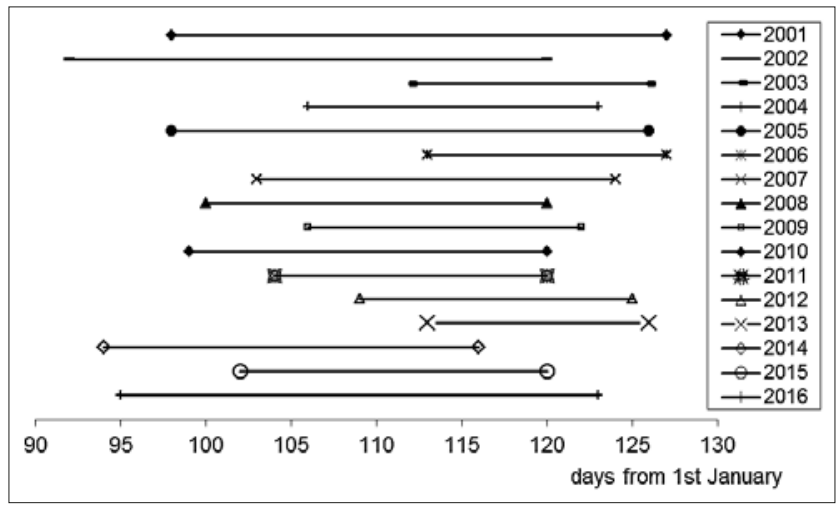

Figure 1. Start and end dates of Fraxinus pollen season in Lublin, 2001-2016

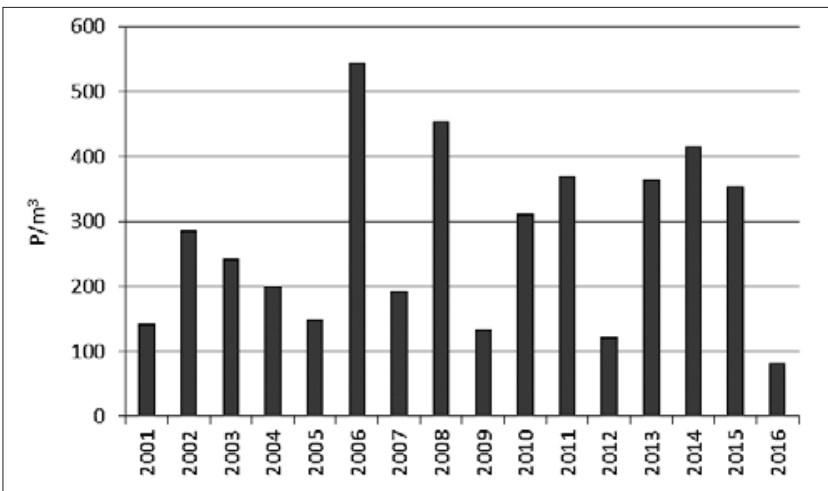

Figure 2. Maximum daily concentration of Fraxinus airborne pollen in Lublin, 2001-2016.

variation between years (Tab. 1). The lowest peak value, which was recorded in 2016, was 6.6 times lower than the highest peak value observed in 2006 (Fig. 2). This plot shows that there is no linear trend in seasonal maximum. Among the years studied, 2006 was characterized by a short season, the latest start and end dates, as well as by the highest peak value and total annual pollen count (Tab. 1). High Fraxinus pollen concentrations exceeding the threshold value were recorded for a maximum of 12 days, whereas the average for the 16year study period was half as small -6 days. It was only in 2016 that no day with a pollen concentration exceeding the value of $90 \mathrm{P} / \mathrm{m}^{3}$ was recorded (Tab. 1).

Statistical analysis revealed a strong negative correlation between start date and season duration, which means that a season that began earlier usually lasted longer, while a
Table 2. List of significant Spearman's correlations between the parameters of Fraxinus pollen season in Lublin (2001-2016)

\begin{tabular}{lc}
\hline Parameters of pollen season & Spearman coefficient \\
\hline Start \& Duration & $-0.9332^{* *}$ \\
\hline Start \& End & $0.4892^{*}$ \\
\hline End \& Peak Date & $0.5801^{*}$ \\
\hline Peak Value \&Annual Total & $0.9000^{* *}$ \\
\hline Level of significance $* 0.05^{* *} 0.01$ &
\end{tabular}

season that began late usually lasted for a shorter time. Peak value and annual total were found to be positively correlated. Correlation analysis also showed that a pollen season that started earlier also ended earlier, and that a season with an earlier end date was characterized by an earlier peak date (a positive correlation) (Tab. 2).

PCA allows reduction in the size of data sets to a much smaller number of independent principal components, explaining the biggest impact on total variability of the original data set, without much loss of information [26]. The determined factor loading values provided almost $82 \%$ of the explained variance of the entire structure by the 2 new variables (Tab. 3). The factor loading values for the PC1 variable indicate that it is most strongly correlated with peak value and annual total; therefore, this factor can be termed as the season's intensity. This variable is also quite largely correlates negatively with the peak value and the end of season. The PC2 variable is most strongly correlated to pollen season start date and season duration (negative correlation). The factor scores shown in the plot, whose axes were the PC1 and PC2, allowed quick identification of the years with similar values of the season characteristics (Fig. 3).

Table 3. Factor loadings after VARIMAX Rotation

\begin{tabular}{lcc}
\hline & PC1 & PC2 \\
\hline Start & 0.004 & $0.986^{*}$ \\
\hline End & -0.548 & 0.617 \\
\hline Duration & -0.352 & $-0.838^{*}$ \\
\hline Peak value & $0.919^{*}$ & 0.113 \\
\hline Annual total & -0.615 & 0.583 \\
\hline Explained variance & $0.918^{*}$ & 0.085 \\
\hline * factor loading value $>0.8$ & $44.52 \%$ & $37.24 \%$ \\
\hline
\end{tabular}

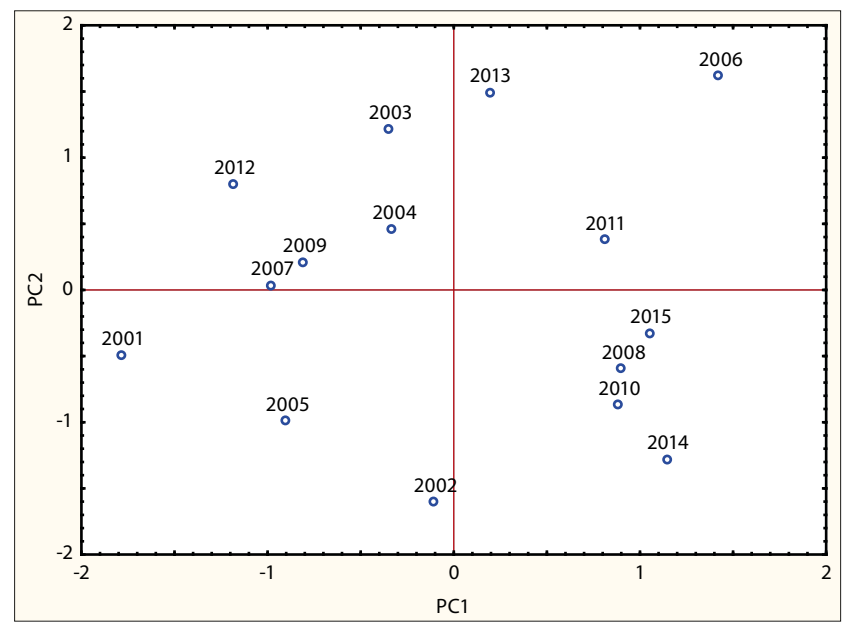

Figure 3. Scatterplot of factor scores in PC1-PC2 coordinate system 
The location of the point corresponding to the 2006 season in the plot indicates that this was a specific season characterized by a late onset, a short duration, and at the same time, very abundant pollen production. Other seasons that started late and lasted relatively short, but with varying airborne pollen intensity, were the seasons in 2003, 2012 and 2013. The graph plot shows that the seasons in 2002, 2005, 2010 and 2014 began earliest and were characterized by a long duration. Moreover, it can be read from the plot that, apart from the year 2006, a high peak value and a high annual total were observed in the seasons in 2008, 2010, 2011, 2014 and 2015. The seasons in 2001, 2005, 2007, 2009 and 2012, characterized by a small amount of airborne pollen and a low peak value, are on the opposite side of the PC1 axis. Additionally, the point for 2001 is the most to the left on the graph, also because, apart from the small concentration of pollen, it was characterized by the late peak and the end of the season. PCA demonstrates that the Fraxinus pollen seasons were most similar in the years 2008, 2010, 2014 and 2015, as well as in 2007 and 2009.

Based on the 2001-2015 data, regression models were developed for pollen season start, end and duration, as well as for peak date and annual total. The fit of the models was at the level of $62-94 \%$ (Tab. 4). Verification of the models was made based on the 2016 data and it so happened that the predicted and actual values were similar (e.g. start, end, duration, peak date - a one-day difference).

Table 4. Regression models for Fraxinus pollen season parameters, based on meteorological factors in Lublin

\begin{tabular}{|c|c|c|}
\hline $\begin{array}{l}\text { Season } \\
\text { parameters }\end{array}$ & Regression equation & $\mathrm{R}^{2}$ \\
\hline Start & 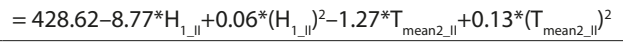 & 0.94 \\
\hline End & $=98.52-0.54 * \mathrm{~T}_{\max 3 \_ \text {II }}+1.76 * \mathrm{C}_{1 \_ \text {III }}+1.82 * \mathrm{C}_{2 \_ \text {IV }}-0.48 * \mathrm{~T}_{\text {mean2_॥ }}$ & 0.62 \\
\hline Duration & $=40.42-0.61 *\left(R_{2 \_}\right)^{2}-0.002 *\left(H_{1 \_\Perp}\right)^{2}+1.38 * T_{\text {mean2 } \_\|}$ & 0.79 \\
\hline Peak date & $\begin{array}{l}=55.10+0.86^{*} \mathrm{~T}_{\min 1-\_}+2.12 * \mathrm{~T}_{\min 1 \_\|}+0.15^{*}\left(\mathrm{~T}_{\min 1 \_\|}\right)^{2}-4.82 * \mathrm{R}_{2 \_-1-} \\
+0.78 * \mathrm{H}_{3 \_-1}-0.18^{*}\left(\mathrm{C}_{3 \_-1}\right)^{2}+0.27^{*}\left(\mathrm{C}_{2 \_-11}\right)^{2}\end{array}$ & 0.85 \\
\hline $\begin{array}{l}\text { Annual } \\
\text { total }\end{array}$ & 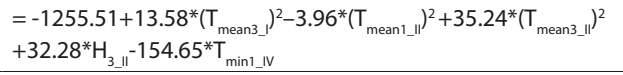 & 0.90 \\
\hline \multicolumn{3}{|c|}{ 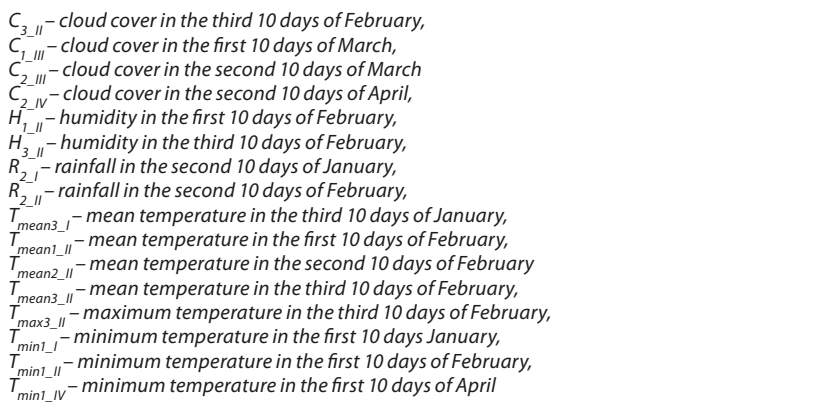 } \\
\hline
\end{tabular}

The best fit was obtained for pollen season start date because the regression equation explained the variation in season start in $94 \%$. The forecast model for pollen season start was based on 2 variables: mean temperature in the second 10 days of February, and air humidity in the first 10 days of February. The difference between the values calculated from the regression equation and the actual values was one day, on average, whereas the greatest deviation between the actual and calculated values was 3 days (in 2011) (Fig.4). The predicted date in 2016 was a day earlier than the actual date.

The regression model describing season end included the following factors: mean temperature in the second 10 days

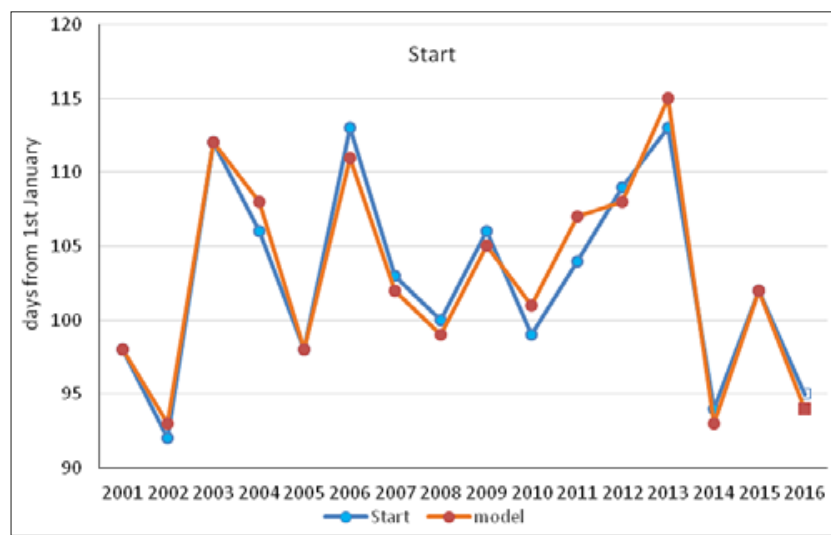

Figure 4. The start date of the Fraxinus pollen season; actual vs. regression model calculated values and predicted value in 2016

of February, maximum temperature in the third 10 days of February, as well as cloud cover in the first 10 days of March and in the second 10 days of April. These variables explain $62 \%$ of the variation in season end dates $\left(\operatorname{Adj}^{2}=0.62\right)$. The difference between the values calculated from the regression equation and the actual values, on average, was 1.3 day. In 2016, the season end was recorded one day earlier than the date predicted on the basis of the regression model (Fig. 5).

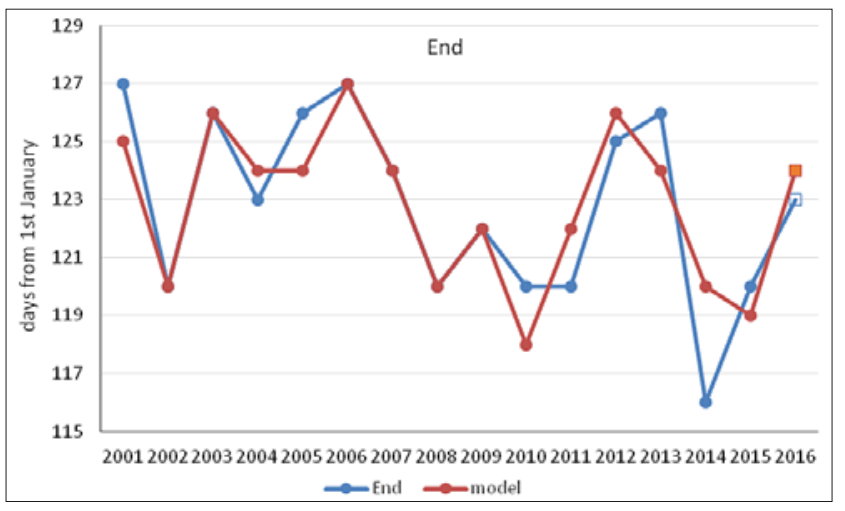

Figure 5. The end date of the Fraxinus pollen season; actual vs. regression model calculated values and predicted value in 2016

Rainfall in the second 10 days of January, humidity in the first 10 days of February, and mean temperature in the second 10 days of February, largely determined Fraxinus pollen season duration. The above-mentioned variables explain $79 \%$ of the variation in this characteristic $\left(\operatorname{Adj\mathrm {R}^{2}}=0.79\right)$. The difference between the values calculated from the regression equation and the actual values, on average, was 1.7 day, whereas the predicted value differed by one day compared to the actual value (Fig.6).

As regards peak date, the difference between the values from the regression equation and the actual values, on average, was one day. The greatest variations between the actual and calculated values (3 days) were found in the years 2007 and 2008. The high adjusted coefficient of determination $\left(A d j \mathrm{R}^{2}=0.85\right)$ demonstrates a significant fitting of the model to the data. The forecast for the seasonal peak date in 2016 was very good and differed by one day from the observed date (Fig.7).

In the case of total annual pollen sum, a good fit of the model $\left(A d j \mathrm{R}^{2}=0.90\right)$ was obtained. The predicted value of total annual pollen sum in 2016 was similar to the actual 


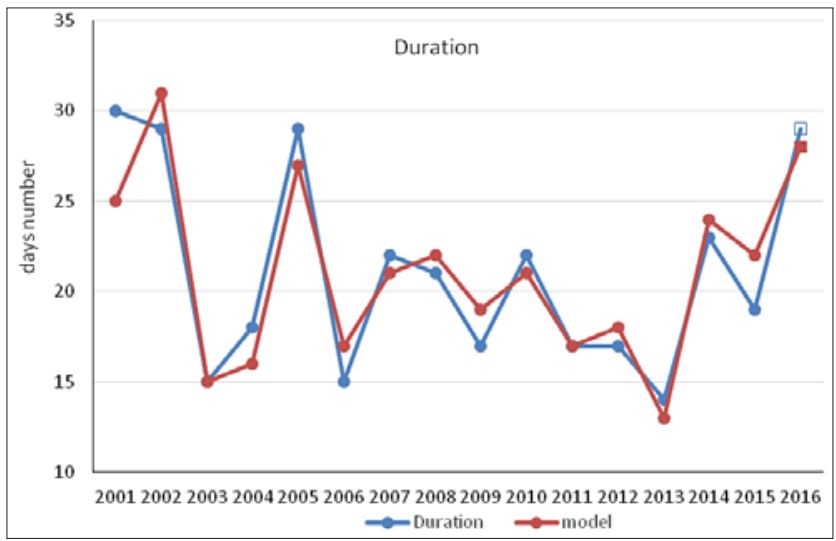

Figure 6. The duration of the Fraxinus pollen season; actual vs. regression model calculated values and predicted value in 2016

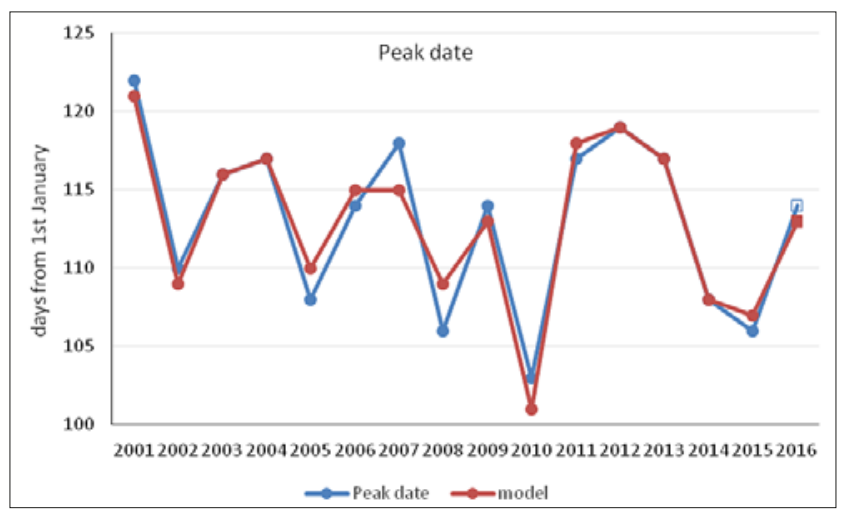

Figure 7. Peak date in Fraxinus pollen season; actual vs. regression model calculated values and predicted value in 2016

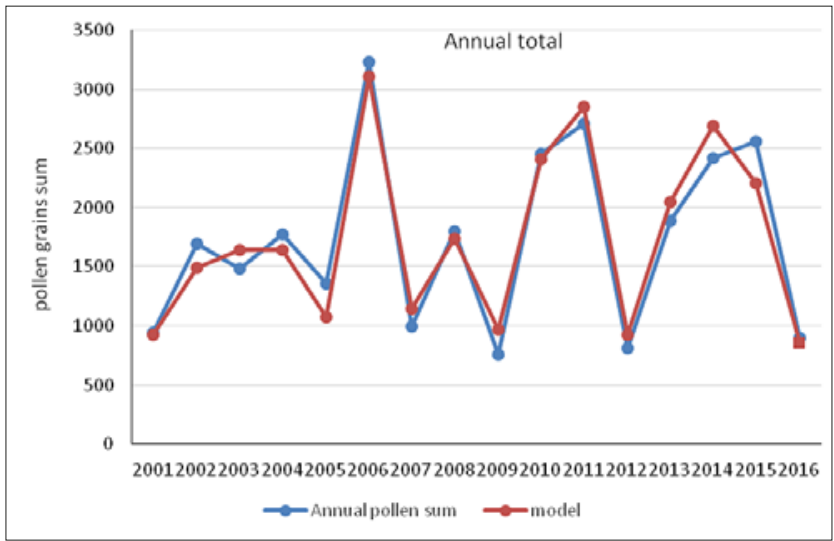

Figure 8. Annual total of Fraxinus pollen; actual vs. regression model calculated values and predicted value in 2016

value (Fig. 8). During the study period, a cyclical decrease was noticed in annual Fraxinus pollen totals every 2-4 years. The annual totals over the last 7 years (2010-2016) were higher (on average 1,962) than in the years 2001-2009 (on average, 1,559).

The layout of points on the above graphs (Fig. 4-8) also indicate that there is no linear trend in seasonal characteristics.

\section{DISSCUSION}

Fraxinus pollen may cause spring pollinosis in areas where it occurs in substantial amounts. High concentrations of this taxon's pollen are recorded in central $[6,27,28,29]$ and southern Europe [30, 31, 32]. The presented study shows that in Poland high Fraxinus pollen concentrations may pose a great threat to allergy sufferers. The results of this study conducted in Lublin reveal that maximum daily concentrations of Fraxinus pollen in central-eastern Poland reach even $545 \mathrm{P} / \mathrm{m}^{3}$, while the average maximum value for the 16 -year study period is $286 \mathrm{P} / \mathrm{m}^{3}$. Analysis of the pollen seasons of Fraxinus in 8 Polish cities during 2001-2005 shows that the highest maximum pollen concentration of this taxon was in Lublin [33]. In the subsequent years of research (2007-2008), there were also higher concentrations of ash pollen in Lublin than in other Polish cities. Additionally, the peak values of this taxon were 1.4-4.4 times higher in Lublin than in other cities $[34,35]$.

In Poland, the maximum Fraxinus pollen concentrations measured at 8 pollen sampling sites ranged between $28-$ $412 \mathrm{P} / \mathrm{m}^{3}$ during the period 2001-2005, and in most cases (64\%) they reached high values [33]. In 2007, at 7 other monitoring sites, maximum values of $44-193 \mathrm{P} / \mathrm{m}^{3}$ were recorded, while in 2008 it was $125-454 \mathrm{P} / \mathrm{m}^{3}$, but in both these years the highest pollen concentrations were found in Lublin. In Poland, the average values for maximum Fraxinus pollen concentrations recorded at the above-mentioned pollen monitoring sites were $87 \mathrm{P} / \mathrm{m}^{3}$ in 2007 and $242 \mathrm{P} / \mathrm{m}^{3}$ in 2008 [34, 35].

In Cordoba and Plasencia, Spain, 59\% and 68\% respectively of patients with a diagnosis of pollinosis were sensitized to European ash tree pollen $[9,36]$. In Locarno and Lugano, Switzerland, $51.8 \%$ of pollen allergic patients were found to be sensitized to ash, whereas in Zurich - 56\% [37, 38]. A study conducted in Vienna, Austria, revealed that the group of Fraxinus pollen-sensitive patients accounted for $17.6 \%$ [6], but in Warsaw - 7.7\% [39]. Based on the analysis of Fraxinus pollen seasons in 7 Polish cities, it was found that the highest number of days with high pollen concentrations was observed in Lublin [34, 35]

The current study shows that in Lublin the Fraxinus pollen season begins in April and ends in the first 10 days of May. Because this is simultaneously the birch pollen season, it can be conclude that the pollen seasons of these 2 taxa cooccur. In Poland, many people suffer from allergies caused by the presence of Betula pollen [10]. Because it has been demonstrated that cross-reactions to pollen allergens of these tree genera may occur [7], attention should be drawn to this fact since it seems to have been ignored to-date.

The timing of Fraxinus pollen seasons in Lublin in particular years significantly varied. It should be stressed that the difference between the latest season start date $(23$ April) and the earliest end date (26 April) was only 3 days (Fig. 1). Air temperature proved to be the factor that most affected the timing of pollen seasons. In the years 2006 and 2013, with the latest onset of the Fraxinus pollen season, the mean monthly temperature in January, February and March was below $0^{\circ} \mathrm{C}$, whereas in 2002, in which the season onset was recorded earliest, the year was characterized by exceptionally warm February and March. A comparison of the data regarding the start dates for the Fraxinus and Betula pollen seasons in Lublin during 2001-2010, reveals that the start of the pollen seasons of these taxa occurred with similar timing, which may be of essential importance for pollen allergic people. A previous study demonstrates that the minimum temperature in February had the greatest effect 
on the Betula pollen season [20]. Fraxinus pollen season was found to be largely modified by meteorological conditions in February (Tab. 4).

In the presented study, PCA method was used to show in one plot the diversity of individual seasons in terms of the investigated season parameters. A similar technique applied to characterize the studied seasons, this time using meteorological characteristics, was presented in the papers concerning Betula [20] and Poaceae pollen concentrations [21]. Graphical presentation of the results obtained using the PCA method facilitates quick evaluation of Fraxinus pollen seasons that have similar characteristics, and allows us to easily find seasons that exhibit significant deviations from the others.

Regression analysis is frequently used in aerobiological research as a casual method of statistical modeling [5]. The relationship between pollen season parameters and meteorological data has been investigated using regression analysis in many studies. The above-mentioned statistical analyses are used to forecast parameters of the pollen seasons of various taxa. For this purpose, average monthly values of weather data are used [17,40,41] or, as in the present study, data from 10-day periods that allowed more accurate regression models to be developed $[42,43,44]$.

\section{CONCLUSIONS}

Fraxinus pollen grains are present in the air of Lublin usually in April and at the beginning of May.

The highest variability was found in the peak value and annual total, while the lowest in the end of the season. There was a strong negative relationship between start and duration and positive between peak value and annual total.

The number of days with concentrations above the established threshold was very different in individual years and the highest in 2011 and 2015, while 2016 was characterized by lack of days with high concentrations.

The PCA graphical presentation allowed seasons with similar parameters to be identified. The year 2006 proved to be the most outlying season, whereas the seasons in 2008, 2010, 2014 and 2015 as well as in 2007 and 2009 were characterized by similarity in terms of season onset, duration and intensity.

In the present study, forecast models were developed for the following season characteristics: start, end, duration, peak date, and total annual pollen sum. The obtained models explain $62-94 \%$ of the variation in the investigated characteristics. The best model fit was obtained for season start, whereas the poorest fit for season end. The predicted values for the individual season characteristics in 2016 which were calculated based on a regression equation were close to the actual values. The analysis of the data showed that weather conditions mainly in February are important factors controlling the Fraxinus pollen season.

\section{REFERENCES}

1. Seneta W, Dolatowski J. Dendrologia. Warszawa: Państwowe Wydawnictwo Naukowe; 2007.

2. Szweykowska A, Szweykowski J. (Eds) Słownik botaniczny. Warszawa: Państwowe Wydawnictwo Wiedza Powszechna; 2003.
3. FRAXIGEN (2005) Ash species in Europe: biological characteristics and practical guidelines for sustainable use. Oxford Forestry Institute, University of Oxford, UK. 128 pp. ISBN: 0850741637.

4. http://herbaria-old.plants.ox.ac.uk/fraxigen/pdfs_and_docs/book/ book.html

5. Dyakowska J. Podręcznik palynologii, Metody i problemy. Wydawnictwa Geologiczne. Warszawa, 1959.

6. Scheifinger H, Belmonte J, Buters J, Celenk S, Damialis A, Dechamp C, et al. Monitoring, modelling and forecasting of the pollen season. In: Sofiev M, Bergmann K-C, editors. Allergenic pollen, Springer Dordrecht Heidelberg New York London 2013. p. 71-126.

7. Hemmer W, Focke M, Wantke F, Götz M, Jarisch R, Jäger S. Ash (Fraxinus excelsior) - pollen allergy in central Europe: Specific role of pollen panallergens and the major allergen of ash pollen, Fra e 1. Allergy 2000; 55: 923-930.

8. Wüthrich B. Esche ist nicht Esche. Allergologie 2006; 29(6): 231-235.

9. Vara A, Fernandez-Gonzalez M, Aira MJ, Rodriguez-Rajo FJ. Oleaceae cross-reactions as potential pollinosis cause in urban areas. Science of the Total Environment 2016; 542: 435-440.

10. Guerra F, Galan C, Daza JC, Miguel R, Moreno C, Gonzalez J, Dominguez E. Study of sensitivity to the pollen of Fraxinus spp. (Oleaceae) in Cordoba, Spain. J Invest Allergol Clin Immunol. 1995; 5(3): 166-170.

11. Samoliński B, Raciborski F, Lipiec A, Tomaszewska A, Krzych-Fałta E, Samel-Kowalik P, et al. Epidemiologia Chorób Alergicznych w Polsce (ECAP). Alergol Pol. 2014; 1: 10-18.

12. Sharifshoushtari M, Majd A, Moin M, Nejadsattari T, Pourpak Z, Khademi R, et al. Ultra structural orbicules released in ash (Fraxinus excelsior) pollen grains and their possible role in allergic respiratory. Allergy 2016; 71 (Suppl. 102): 191-192.

13. Kasprzyk I, Uruska A, Szczepanek K, Latałowa M, Gaweł J, Harmata K, Myszkowska D, Stach A, Stępalska D. Regional differentiation in the dynamics of the pollen seasons of Alnus, Corylus and Fraxinus in Poland (preliminary results). Aerobiologia 2004; 20: 141-151.

14. Weryszko-Chmielewska E, Puc M, Piotrowska K. Effect of meteorological factors on Betula, Fraxinus and Quercus pollen concentrations in the atmosphere of Lublin and Szczecin, Poland. Ann Agric Environ Med. 2006; 13: 243-249.

15. Puc M. Influence of meteorological parameters and air pollution on hourly fluctuation of birch (Betula L.) and ash (Fraxinus L.) airborne pollen. Ann Agric Environ Med. 2012; 19(4): 660-665.

16. Horak F, Hussarke M, Jäger S, Skoda-Türk R. Die Bestimmung der Aggressivität allergisierender Pollenarten. Wiener klinische Wochenschrift. 1979; 92: 161-164.

17. Frenz DA. Interpreting atmospheric pollen counts for use in clinical allergy: allergic symptomology. Ann Allergy Asthma Immunol. 2001; 86: $150-158$.

18. Stach A, Smith M, Prieto Baena JC, Emberlin J. Long-term and short-term forecast models for Poaceae (grass) pollen in Poznan, Poland, constructed using regression analysis. Environmental and Experimental Botany 2008; 62: 323-332.

19. Piotrowska K. Forecasting the Poaceae pollen season in eastern Poland. Grana. 2012; 51(4): 263-269.

20. Myszkowska D. Prediction of the birch pollen season characteristics in Cracow, Poland using an 18-year data series. Aerobiologia 2013; 29(1): 31-44.

21. Piotrowska K, Kubik-Komar A. The effect of meteorological factors on airborne Betula pollen concentrations in Lublin (Poland). Aerobiologia 2012; 28: 467-479.

22. Piotrowska K, Kubik-Komar A. A comparative analysis of Poaceae pollen seasons in Lublin (Poland). Acta Agrobot. 2012; 65(4): 39-48.

23. Mandrioli P, Comtois P, Dominguez Vilches E, Galan Soldevilla C, Syzdek L, et al. Sampling: principles and techniques. In: Mandrioli $\mathrm{P}$, Comtois P, Levizzani V, editors. Methods in Aerobiology. Pitagora Editrice Bologna, Bologna. 1998.

24. Andersen TB. A model to predict the beginning of the pollen season. Grana. 1991; 30: 269-275.

25. Krzyśko M. Multivariate Statistical Analysis. UAM - Poznań, 2000.

26. Grala-Michalak J, Kaźmierczak K. The approximation of tree volume based on measurements of biometric features of standing scots pine trees. Colloquium Biometricum. 2013; 43: 5-11.

27. Jakubus M, Graczyk M. Evaluation of the usability of single extractors in chemical analysis of composts using principal component analysis. Biometrical Letters. 2015; 52(2): 115-130.

28. Kernerman SM, McCullough J, Green J, Ownby DR. Evidence of crossreactivity between olive, ash, privet, and Russian olive tree pollen allergens. Ann Allergy. 1992; 69(6): 493-496. 
29. Niederberger V, Purohit A, Oster JP, Spitzauer S, Valenta R, Pauli G The allergen profile of ash (Fraxinus excelsior) pollen: cross-reactivity with allergens from various plant species. Clin Exp Allergy. 2002; 32: 933-941.

30. Geburek T, Hiess K, Litschauer R, Milasowszky N. Temporal pollen pattern in temperate trees: expedience or fate? Oikos. 2012; 121: 1603 1612.

31. Barderas R, Purohit A, Papanikolaou I, Rodriguez R, Pauli G, Villalba M. Cloning, expression, and clinical significance of the major allergen from ash pollen, Fra e 1. J Allergy Clin Immunol. 2005; 115: 351-357.

32. Gastaminza G, Bartolome B, Bernedo N, Uriel O, Audicana MT, Echenagusia MA, et al. Oleaceae pollen allergy in a place where there's no olive trees. Alergol Immunol Clin. 2005; 20(4): 131-138.

33. Stefanic E, Rasic S, Merdic S, Colakovic K. Annual variation of airborne pollen in the city of Vinkovci, Northeastern Croatia. Ann Agric Environ Med. 2007; 14: 97-101.

34. Weryszko-Chmielewska E. (Ed.) Pyłek roślin w aeroplanktonie różnych regionów Polski. Wyd. Katedry i Zakładu Farmakognozji AM w Lublinie; 2006

35. Lipiec A, Weryszko-Chmielewska E, Piotrowska K, Chłopek K, Malkiewicz M, Puc M, et al. Analiza stężenia pyłku jesionu w wybranych miastach Polski w 2007 r. Alergoprofil. 2007; 3(3): 50-54.

36. Puc M, Rapiejko P, Myszkowska D, Weryszko-Chmielewska E, Piotrowska K, Chłopek K, et al. Pyłek jesionu w powietrzu wybranych miast Polski w roku 2008. Alergoprofil 2008; 4(3): 35-39.
37. Cosmes MPM, Moreno AA, Dominiguez NC, Gutierrez VA, Belmonte SJ, Roure NJM. Sensitization to Castanea sativa pollen and pollinosis in northern Extremadura (Spain). Allergol Immunopathol. 2005; 33(3): $145-150$.

38. Schmid-Grendelmeier P, Peeters AG, Wahl R, Wüthrich P. Zur Bedeutung der Eschenpollenallergie. Allergologie 1994; 17: 535-542.

39. Colombo V. Zum Sensibilisierungsspektrum von Pollenallergikern im Kanton Tessin. Eine prospektive Studie In Locarno Und Lugano 2009. Thesis. Zurich: University of Zurich 2010.

40. Rapiejko P. Alergeny pyłku jesionu. Alergoprofil. 2008; 4(1): 46-48.

41. Galan C, Garcia-Mozo H, Carinanos P, Alcazar P, Dominguez-Vilches E. The role of temperature in the onset of the Olea europea L. pollen season in southwestern Spain. Int J Biometeorol. 2001; 45(1): 8-12.

42. Piotrowska-Weryszko K. The effect of the meteorological factors on the Alnus pollen season in Lublin (Poland). Grana. 2013; 52: 221-228.

43. Laaidi M. Forecasting the start of the pollen season of Poaceae: evaluation of some methods based on meteorological factors. Int J Biometeorol. 2001; 45:1-7.

44. Smith M, Emberlin J. Constructing a 7-day ahead forecast model for grass pollen at north London, United Kingdom. Clin Exp Allergy. 2005; 35: 1400-1406.

45. Piotrowska-Weryszko K. Artemisia pollen in the air of Lublin, Poland (2001-2012). Acta Sci Pol, Hortorum Cultus. 2013; 12(5): 155-168. 